\title{
EHD1 Gene
}

National Cancer Institute

\section{Source}

National Cancer Institute. EHD1 Gene. NCI Thesaurus. Code C126473.

This gene is involved in endocytosis and recycling of the plasma membrane. 